\title{
Hubungan Kadar Serum Erithropoietin Dengan Transferin Pada Ibu Hamil Anemia Dan Ibu Hamil Normal
}

\author{
Epi Satria ${ }^{1}$, Arni Amir $^{2}$, Vaulinne ${ }^{3}$
}

\begin{abstract}
Abstrak
Penyebab anemia dalam kehamilan yaitu akibat defisiensi besi. Pemeriksaan ertitropoietin dan transferin menjadi alternatif dalam mengidentifikasi anemia defisiensi besi pada ibu hamil. Tujuan penelitian adalah menentukan hubungan kadar serum erithropoietin terhadap transferin pada ibu hamil anemia dan ibu hamil normal. Penelitian dilakukan dengan menggunakan desain cross sectional comparative study. Penelitian dilakukan di wilayah kerja Puskesmas Kuranji pada bulan November 2018 sampai Januari 2019. Populasi pada penelitian ini adalah ibu hamil anemia dan hamil normal dengan jumlah sampel 64 orang pada dua kelompok. Pengambilan sampel dengan consecutive sampling. Pemeriksaan kadar eritropoietin dan transferin dilakukan di laboratorium Biomedik Fakultas Kedokteran Unand dengan metode ELISA. Uji normalitas data dengan uji Shapiro-Wilk dan uji t tidak berpasangan dan korelasi pearson. Hasil penelitian menunjukkan rerata kadar eritropoietin pada ibu hamil anemia yaitu $69,83 \pm 20,21$ $\mathrm{mU} / \mathrm{ml}$, dan $57,81 \pm 21,86 \mathrm{mU} / \mathrm{ml}$ pada ibu hamil normal $(\mathrm{p}<0,05)$. Rerata kadar transferin pada ibu hamil anemia yaitu $203,32 \pm 77,66 \mathrm{ng} / \mathrm{ml}$, dan $165,63 \pm 65,12 \mathrm{ng} / \mathrm{ml}$ pada ibu hamil normal $(p<0,05)$. Terdapat hubungan kadar eritropoietin dengan transferin pada ibu hamil anemia $(p<0,05)$. Spulan penelitian ini ialah terdapat perbedaan rerata kadar eritropoietin dan transferin pada ibu hamil anemia dan normal. Terdapat hubungan kadar serum erithropoietin dengan transferin pada ibu hamil anemia, namun tidak terdapat hubungan kadar serum erithropoietin dengan transferin pada ibu hamil normal.
\end{abstract}

Kata kunci: anemia, eritropoietin, transferin, ibu hamil

\begin{abstract}
Examination of eritropoietin and transferrin is an alternative in identifying iron deficiency anemia in pregnant women. The objective of this study was to investigate the relationship between serum of erythropoietin and transferrin levels of anemia on pregnancy and normal pregnancy. This research was cross sectional comparative study design. The research was in the working area of primary health care Kuranji in November 2018 until January 2019. The population in this study were all anemia in pregnancy and normal pregnancy with sample size sixty four people in two groups. Sampling technique with consecutive sampling. The examination of erythropoietin and transferrinlevels was performed in Biomedical Laboratory of Faculty of Medicine Unand by ELISA method. Test of data normality with Shapiro-Wilk test and independent sample t-test and Pearson correlation for hyphotesis. The results showed that mean of erythropoietin level of anemia in pregnancy were $69,83 \pm 20,21 \mathrm{mU} / \mathrm{ml}$ and 57,81 $\pm 21,86 \mathrm{mU} / \mathrm{mlin}$ normal pregnancy $(p<0.05)$. The mean of transferrin level in normal pregnancy were $203,32 \pm 77,66 \mathrm{ng} / \mathrm{ml}$ and $165,63 \pm 65,12$ $\mathrm{ng} / \mathrm{ml}$ in normal pregnancy $(p<0.05)$. There was relationship between erythropoietin and transferrin levels with anemia pregnancy $(p>0.05)$. The conclusion of this study is the significant difference of erythropoietin and transferrin levels on anemia pregnancy and normal pregnancy. There is a correlation between serum levels of erythropoietin and transferrin on anemic pregnant women, but there is no correlation between serum levels of erythropoietin and transferrin on normal pregnantcy women.
\end{abstract}

Keywords: anemia, erythropoietin, transferrin, pregnant's mother 
Affiliasi penulis: 1. Stikes YPAK Padang, 2. Bagian Biologi Fakultas Kedokteran Unviersitas Andalas Padang, 3. Bagian Fetomaternal Obstetri Ginekologi RSUD Rasidin Padang.

Korespondensi: Arni Amir, Email:amir_arni@yahoo.com HP: 081266393349

\section{PENDAHULUAN}

Prevalensi anemia pada ibu hamil di Indonesia tahun 2018 yaitu 48,9\%, ${ }^{1}$ lebih tinggi dibandingkan tahun 2013 sebesar $37,1 \%{ }^{2}$ dan tahun 2007 yaitu $24,5 \%{ }^{3}$ Menurut data Dinas Kesehatan Kota Padang menunjukkan bahwa prevalensi anemia pada ibu hamil tahun 2017 adalah 19,8\% sedikit lebih rendah dibandingkan tahun 2014 sebesar 20,7\%. Prevalensi anemia pada ibu hamil di Kota Padang tahun 2018 adalah sebesar $7,2 \%$. Berdasarkan data masingmasing puskesmas di Kota Padang terdapat tiga puskesmas dengan prevalensi anemia ibu hamil tertinggi yaitu Puskesmas Anak Air (27,92\%), Puskesmas Seberang Padang (20,33\%) dan Puskesmas Kuranji (13,78\%). ${ }^{4}$

Anemia defisiensi besi akan mempunyai pengaruh sangat besar terhadap perkembangan otak bayi di masa yang akan datang.Berdasarkan hal tersebut perlu adanya upaya pencegahan bahaya anemia defisiensi besi ibu hamil, salah satunya dengan dilakukannya diagnosis dini anemia difisiensi besi yang biasanya dilakukan dengan mengukur kadar hemoglobin dan dengan memperkirakan indeks darah seperti mean corpuscular volume (MCV), mean corpuscular hemoglobin (MCH), mean corpuscular hemoglobinconcentration ( $\mathrm{MCHC})$, kadar besi serum, kapasitas pengikatan total besi/ total iron binding capacity (TIBC) dan serum ferritin. ${ }^{5}$ Serum ferritin merupakan petunjuk kadar cadangan besi dalam tubuh. Pemeriksaan kadar serum ferritin sudah rutin dikerjakan untuk menentukan diagnosis defisiensi besi, karena terbukti bahwa kadar serum ferritin sebagai indikator paling dini menurun pada keadaan bila cadangan besi menurun, namun dalam keadaan infeksi kadarnya dipengaruhi, sehingga dapat mengganggu interpretasi keadaan sesungguhnya. ${ }^{6}$

Eritropoietin menyebabkan kondisi eritropoesis defisiensi besi yang akan menyebabkan siklus sel menjadi lambat dan pembelahan sel terganggu. Erythropoietin menstimulasi (merangsang) sumsum tulang (bone marrow) untuk menghasilkan lebih banyak sel-sel darah merah. Kenaikan eritropoeitin dalam sel-sel merah meningkatkan kapasitas darah dalam mengangkut oksigen. Eritropoeitin sebagai pengatur utama dari produksi sel darah merah, fungsi utama erythropoietin adalah untuk memajukan perkembangan dari sel-sel darah merah dan memulai sintesis dari hemoglobin, molekul didalam sel-sel darah merah yang mengangkut oksigen. ${ }^{7}$

Pada saat ini terdapat pemeriksaan dengan mengetahui kadar reseptor transferin serum (sTfR) dalam mengidentifikasi anemia defisiensi besi, yang memiliki keunggulan tidak terpengaruh oleh peradangan dan merupakan penanda yang sensitif dan spesifik untuk anemia defisiensi besi. Hal ini disebabkan karena pengukuran ulang kadar sTfR telah diketahui memiliki variabilitas biologi yang rendah. Tingkat reseptor transferin serum meningkat dan indeks sTfR/ feritin menurun pada anemia defisiensi besi. $^{8}$

Pada penelitian ini dilakukan pengukuran kadar serum erithropoietin dan transferin pada ibu hamil trimester III. Hal ini disebabkan volume darah akan bertambah dalam kehamilan dimulai pada 10 minggu pertama kehamilan dan mencapai puncaknya dalam kehamilan antara 32 dan 36 minggu. Secara fisiologis, pengenceran darah ini untuk membantu meringankan kerja jantung yang semakin berat dengan adanya kehamilan. $^{7}$ Perubahan hematologi sehubungan dengan kehamilan adalah oleh karena perubahan sirkulasi yang makin meningkat terhadap plasenta dan pertumbuhan payudara. Volume plasma meningkat 45\%-65\% dimulai trimester II kehamilan dan maksimum terjadi pada bulan ke $9 .^{9}$

Penelitian ini bertujuan untuk mengetahui hubungan serum erithropoietin dan transferin pada ibu hamil anemia dan ibu hamil normal

\section{METODE}

Jenis penelitian ini adalah ekspremental dengan desain cross sectonal comparative study. Jumlah sampel masing-masing kelompok 32 orang dari bulan september sampai dengan desember 2018 di Laboratorium Biomedik Fakultas Kedokteran Universitas Andalas Padang. Darah didiamkan selama 2 jam di suhu kamar sebelum dilakukan sentrifus, botol darah dimasukkan ke dalam alat sentrifus kemudian 
disentrifus selama 15 menit dengan kecepatan 3000 rpm untuk mendapatkan serum. Serum yang didapat disimpan pada botol serum yang telah diberi label dengan masing-masing identitas pasien, kemudian diletakkan pada rak di dalam lemari pendingin bersuhu $-20^{\circ} \mathrm{C}$. Botol serum diletakkan pada rak di dalam cooler bag yang dilengkapi dengan ice gel yang bisa bertahan hingga maksimal 6 jam,penyimpanan serum dilanjutkan di lemari pendingin bersuhu $-20^{\circ} \mathrm{C},-40^{\circ} \mathrm{C}$ atau $-80^{\circ}$ C. Langkah selanjutnya dilakukan pemeriksaan eritropoietin dan transferin diukur menggunakan elisa kit (ELISA)

Normalitas data dilakukan dengan uji Shapiro Wilk, apabila data terdistribusi normal menggunakan uji independent t-test, namun apabila data berdistribusi tidak normal digunakan uji Mann whitney.

\section{HASIL}

Penelitian telah dilakukan untuk mengetahui hubungan kadar serum erithropoietin dengan transferin pada ibu hamil anemia dan ibu hamil normal yang dilakukan terhadap 64 pasien berdasarkan pendekatan cross sectional comparative study. Subjek penelitian terdiri dari masing-masing 32 responden pada ibu hamil anemia dan ibu hamil normal yang diambil di wilayah kerja Puskesmas Kuranji Padang.

Tabel 1. Perbedaan rerata serum erithropoietin pada ibu hamil anemia dan ibu hamil normal

\begin{tabular}{lccc}
\hline \multirow{2}{*}{ Variabel } & \multicolumn{2}{c}{ Ibu Hamil } & \\
\cline { 2 - 3 } & $\begin{array}{c}\text { Anemia } \\
\text { (rerata } \pm \text { SD) }\end{array}$ & $\begin{array}{c}\text { Normal } \\
\text { (rerata } \pm \text { SD) }\end{array}$ & $\mathbf{p}$ \\
\hline Kadar & $69,83 \pm 20,21$ & $57,81 \pm 21,86$ & 0,026 \\
Erithropoietin & & & \\
$(\mathrm{mU} / \mathrm{ml})$ & & & \\
\hline
\end{tabular}

Hasil Tabel 1 diketahui bahwa rerata kadar erithropoietin pada ibu hamil anemia yaitu 69,83 \pm $20,21 \mathrm{mU} / \mathrm{ml}$, sedangkan rerata kadar erithropoietin pada ibu hamil normal yaitu 57,81 $\pm 21,86 \mathrm{mU} / \mathrm{ml}$. Hasil uji statistik independent t-test didapatkan nilai $p=0,026(p<0,05)$ maka dapat disimpulkan terdapat perbedaan yang bermakna rerata serum erithropoietin pada ibu hamil anemia dan ibu hamil normal.
Tabel 2. Perbedaan rerata serum transferin pada ibu hamil anemia dan ibu hamil normal

\begin{tabular}{lccc}
\hline \multirow{2}{*}{ Variabel } & \multicolumn{2}{c}{ Ibu Hamil } & \\
\cline { 2 - 3 } & $\begin{array}{c}\text { Anemia } \\
\text { (rerata } \pm \text { SD) }\end{array}$ & $\begin{array}{c}\text { Normal } \\
\text { (rerata } \pm \text { SD) }\end{array}$ & $\mathbf{p}$ \\
\hline Kadar & $203,32 \pm$ & $165,63 \pm$ & 0,039 \\
Tranferin & 77,66 & 65,12 & \\
$(\mathrm{ng} / \mathrm{ml})$ & & & \\
\hline
\end{tabular}

Hasil Tabel 2 diketahui bahwa rerata kadar tranferin pada ibu hamil anemia yaitu 203,32 \pm 77,66 $\mathrm{ng} / \mathrm{ml}$, sedangkan rerata kadar transferin pada ibu hamil normal yaitu $165,63 \pm 65,12 \mathrm{ng} / \mathrm{ml}$. Hasil uji independent $t$-test didapatkan nilai $p=0,039(p<0,05)$ maka dapat disimpulkan terdapat perbedaan yang bermakna rerata serum transferin pada ibu hamil anemia dan ibu hamil normal.

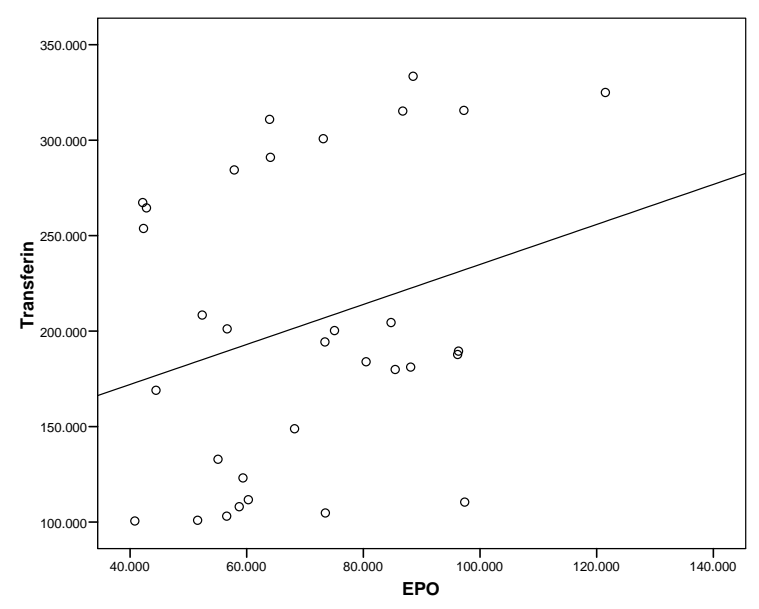

Gambar 1. Hubungan kadar serum erithropoietin dengan transferin pada ibu hamil anemia dan ibu hamil normal

Gambar 1 diketahui bahwa korelasi kadar serum erithropoietin dan transferin pada ibu hamil anemia memiliki arah positif artinya apabila terjadi peningkatan kadar serum erithropoietin maka akan terjadi peningkatan kadar transferin. Berdasarkan hasil ujikorelasi pearson diketahui bahwa terdapat hubungan kadar serum erithropoietin dengan transferin pada ibu hamil anemia dengan nilai $\mathrm{p}=$ 0,031 ( $p<0,05$ ) dengan kekuatan hubungan lemah yaitu $r=0,273$. 


\section{PEMBAHASAN}

Hasil penelitian diketahui bahwa rerata kadar erithropoietin pada ibu hamil anemia yaitu 69,83 \pm $20,21 \mathrm{mU} / \mathrm{ml}$, sedangkan rerata kadar erithropoietin pada ibu hamil normal yaitu 57,81 $\pm 21,86 \mathrm{mU} / \mathrm{ml}$. Hasil uji independent $t$-test didapatkan nilai $\mathrm{p}=0,026$ $(p<0,05)$ maka dapat disimpulkan terdapat perbedaan yang bermakna rerata serum erithropoietin pada ibu hamil anemia dan ibu hamil normal.

Eritropoietin menyebabkan kondisi eritropoesis defisiensi besi yang akan menyebabkan siklus sel menjadi lambat dan pembelahan sel terganggu. Erythropoietin menstimulasi (merangsang) sumsum tulang untuk menghasilkan lebih banyak sel-sel darah merah. $^{10}$

Pengaruh eritropoietin dalam pembentukan sel darah merah adalah merangsang produksi proeritroblas dari sel stem hematopoietik di sum sum tulang. Proeritroblas terbentuk, maka eritropoietin juga menyebabkan sel-sel ini dengan cepat melalui berbagai tahap eritroblastik ketimbang pada dalam keadaan normal. Hal tersebut akan lebih mempercepat produksi sel darah merah yang baru. Produksi sel ini terus berlangsung selama orang tersebut tetap dalam oksigen rendah atau sampai jumlah sel darah merah yang telah terbentuk cukup untuk mengangkut oksigen dalam jumlah yang memadai walaupun kadar oksigennya rendah. Pada saat ini, kecepatan produksi eritropietin menurun sampai kadar tertentu yang akan mempertahankan jumlah sel darah merah yang dibutuhkan, namun sampai tidak berlebihan. ${ }^{10}$

Bila tidak ada eritropoietin, sumsum tulang hanya membentuk sedikit sel darah merah. Pada keadan lain yang ekstrem bila jumlah eritropoietin yang berbentuk sangat banyak, dan jika tersedia sejumlah besar zat besi dan zat nutrisi yang diperlukan,maka kecepatan produksi sel darah merah dapat meningkatkan sampai sepuluh kali lipat atau dibandingkan keadaan normal. Oleh karena itu, mekanisme eritropoietin dalam memproduksi sel darah merah merupakan suatu mekanisme yang kuat. ${ }^{7}$

Akibatnya, volume plasma bertambah dan Sel Darah Merah (SDM) meningkat. Peningkatan volume plasma terjadi dalam proporsi yang lebih besar jika dibandingkan dengan peningkatan eritrosit sehingga terjadi penurunana konsentrasi $\mathrm{Hb}$ akibat hemodilusi. Keadaan tersebut mempengaruhi hemoglobin ibu hamil yang mendapat mengalami anemia selama kehamilan. $^{7}$

Penelitian ini sejalan dengan penelitian tentang perbedaan kadar erithropoietin pada ibu hamil anemia dan ibu hamil normal, kadar erithropoietin pada ibu hamil anemia 26,24 $\pm 26,61 \mathrm{mU} / \mathrm{ml}$ lebih tinggi dibandingkan kehamilan normal 18,12 $\pm 19,08 \mathrm{mU} / \mathrm{ml}$ $(p=0,044, p<0,05) .{ }^{12}$ Identifikasi anemia defisiensi besi pada ibu hamil dapat dilihat berdasarkan konsentrasi erithropoietin yang meningkat di atas batas referensi (> 31,5 mlU/ mL). ${ }^{9}$ Pada penelitian ini didapatkan $16 \%$ dari semua wanita hamil yang menjadi responden penelitian mengalami anemia defisiensi besi.

Hasil penelitian ini sejalan dengan penelitian tentang perbedaan kadar eritropoietin pada ibu hamil anemia dibandingkan normal dan dapat digunakan untuk mendiagnosis defisiensi besi. ${ }^{5}$ Diperkuat dengan penelitian Khalid et al yang menyatakan terdapat perbedaan kadar eritropoietin pada ibu hamil anemia berat, sedang dan ringan dengan $p=0,004(p<0,05) .{ }^{6}$

Hasil penelitian diketahui rerata kadar tranferin pada ibu hamil anemia yaitu 203,32 \pm 77,66 ng/ml, sedangkan rerata kadar transferin pada ibu hamil normal yaitu $165,63 \pm 65,12 \mathrm{ng} / \mathrm{ml}$. Hasil uji statistik independent $T$ test didapatkan nilai $p=0,039(p<0,05)$ maka dapat disimpulkan terdapat perbedaan rerata serum transferin pada ibu hamil anemia dan ibu hamil normal.

Protein berperan penting dalam transportasi zat besi dalam tubuh. Kekurangan asupan protein akan mengakibatkan transportasi zat besi terhambat sehingga akan terjadi defisiensi besi. Transferin merupakan protein utama pengangkut zat besi, suatu beta globulin dan sintesis di hepar.Tiap molekul transferin dapat mengikat dua molekul besi dalam bentuk ferri. Transferin akan membawa zat besi ke sumsum tulang atau ke organ lain, apabila sumsum tulang mengalami kerusakan atau kelebihan jumlah zat besi yang siap disimpan dalam sumsum tulang. Pada saat tidak ada transferin, protein lain akan mengikat zat besi tetapi membawa zat besi ke organ lain seperti hepar, limpa, pankreas dan sedikit ke sumsum tulang. Transferin mempunyai reseptor spesifik pada besi maupun ke sel dan normoblast 
yang baru berkembang. Transferin yang sudah membawa zat besi berikatan dengan reseptor transferin pada permukaan prekursor entroid. Dalam sel eritroid sebagian besar zat besi pindah ke mitokondria, dimana akan bergabung dengan protoporfirin untuk membentuk heme. Dalam sel noneritroid zat besi disimpan sebagai ferritin dan hemosiderin. Ferritin terdiri dari tempurung protein bagian luarnya dan kompleks zat besi dibagian tengah atau intinya. Tempurung bagian luarnya terdiri dari 22 molekul apoferritin dan intinya terdiri dari fosfat/zat besi. $^{8}$

Jika asupan protein rendah maka proses transferrin mengangkut zat besi kesumsum tulang belakang akan terhambat. Menurunnya asupan protein dan zat besi yang merupakan unsur utama pembentukan hemoglobin akan mempengaruhi kadar produksi hemoglobin. Untuk mencegah agar tidak kekurangan kadar hemoglobin dan mengalami anemia, maka salah satu yang perlu diperhatikan adalah asupan makanan yang mengandung zat besi seimbang. ${ }^{11}$

Peningkatan ini sejalan tentang kadar serum transferin pada ibu hamil anemia 1,40 $\pm 0,0802 \mu \mathrm{g} / \mathrm{mL}$ lebih tinggi dibandingkan ibu hamil yang normal $1,08 \pm 0,641 \mu \mathrm{g} / \mathrm{mL} \quad(p=0,019, \quad p<0,05) .{ }^{9}$ Namun jika dibandingkan pada klasifikasi anemia ibu hamil, kadar transferin lebih tinggi pada ibu dengan anemia berat dibandingkan sedang dan ringan $(2.28 \pm 0.986 \mu \mathrm{g} / \mathrm{ml}$, $1.4 \pm 0.816 \mu \mathrm{g} / \mathrm{ml}$ dan $1.16 \pm 0.702 \mu \mathrm{g} / \mathrm{ml})(p=0,001$, $\mathrm{p}<0,05)^{8}$

Serum transferin secara signifikan lebih tinggi ( $p<0,05)$ pada trimester ketiga dibandingkan dengan trimester pertama dan kedua. Temuan dari penelitian ini menunjukkan bahwa pengukuran kadar serum transferin dapat menjadi parameter yang lebih baik untuk memprediksi kehamilan dan disarankan bersama dengan penyelidikan hematologi rutin lainnya. $^{6}$

Hasil penelitian ini sejalan dengan Flesland et al kadar transferin pada ibu hamil anemia dibandingkan normal dan dapat digunakan untuk mendiagnosis defisiensi besi. ${ }^{12}$

Hasil penelitian diketahui korelasi kadar serum erithropoietin dan transferin pada ibu hamil anemia memiliki arah positif artinya apabila terjadi peningkatan kadar serum erithropoietin maka akan terjadi peningkatan kadar transferin. Berdasarkan hasil uji statistik korelasi pearson diketahui bahwa terdapat hubungan kadar serum erithropoietin dengan transferin pada ibu hamil anemia dengan nilai $p=$ $0,031(p<0,05)$ dengan kekuatan hubungan lemah yaitu $r=0,273$. Tidak terdapat hubungan kadar serum erithropoietin dengan transferin pada ibu hamil normal dengan nilai $p=0,936(p>0,05)$.

Penelitian ini terdapat perbedaan dengan penelitian Sharma et al yang menyatakan terdapat hubungan kadar eritropoietin dengan transferin pada ibu hamil anemia dan ibu hamil normal $(p<0,05){ }^{9}$ sedangkan peneliti dapatkan tidak terdapat hubungan. hal ini disebabkan karena umur responden pada penelitian ini yaitu 28 tahun sedangkan rerata umur peneliti dapatkan 30 tahun,

Kejadian anemia defisiensi besi berkaitan dengan produksi sel darah merah. Dalam memproduksi sel darah merah terdapat senyawa glikoprotein yang mengendalikan proseseritropoiesis (produksi sel darah merah) yang disebut dengan erithropoietin yang merupakan hormon di ginjal yang dilepaskan sebagai respons terhadap hipoksia jaringan karena peningkatan kebutuhan oksigen untuk mengurangi pengiriman jaringan dan merangsang produksi sel darah merah di sumsum tulang. ${ }^{10}$ Tingkat serum erithropoietin (serum EPO) berbanding terbalik dengan konsentrasi hemoglobin dan juga aktivitas sumsum tulang. Ada beberapa bukti bahwa terjadi penurunan kadar erithropoietin pada awal kehamilan, tetapi mengalami peningkatan pada kehamilan lanjut. ${ }^{8}$

Pada saat tubuh kekurangan zat besi, absorpsi akan meningkat, begitu pula saat tubuh cukup zat besi, absorpsi akan menurun. Zat besi diabsorpsi terutama dalam mukosa duodenum. Saat zat besi akan digunakan untuk metabolisme, zat besi akan diangkut oleh transferrin menuju sumsum tulang (80\%) ataupun jaringan - jaringan lain. ${ }^{13}$

Terdapatnya hubungan kadar serum erithropoietin dengan transferin pada ibu hamil anemia dan ibu hamil normal dapat dijelaskan bahwa kehamilan kebutuhan oksigen lebih tinggi sehingga memicu peningkatan produksi eritropoietin. Akibatnya, volume plasma bertambah dan sel darah merah (eritrosit) meningkat. ${ }^{14}$ 
Pada ibu hamil dengan defisiensi besi produksi eritropoetin ini secara drastis lebih tinggi dibandingkan normal sebagai respon pengambilan cadangan penyimpanan besi, kondisi ini menyebabkan peningkatan volume plasma dan terjadinya proses transport sel darah merah dari sumber cadangan besi di sumsum tulang belakang melalui transferin, sehingga kadar transferin juga meningkat dalam darah. Kondisi ini memicu menggambarkan proporsi yang lebih besar jika dibandingkan dengan peningkatan eritrosit sehingga terjadi penurunan konsentrasi hemoglobin $(\mathrm{Hb})$. Apabila kondisi ini berlangsung secara terus menerus akan menyebabkan terganggunya transfer oksigen ke jaringan dan menyebabkan terhambat pertumbuhan janin. ${ }^{12}$ Kondisi eritropoesis defisiensi besi ini akan menyebabkan siklus sel menjadi lambat dan pembelahan sel terganggu sehingga menyebabkan proliferasi sel terganggu dan menghambat proses angiogenesi serta transpor nutrisi ke plasenta janin, sehingga pertumbuhan janin yang terganggu. ${ }^{9}$

Pemeriksaan anemia defisiensi ibu hami dengan pemeriksaan serum ferritin merupakan petunjuk kadar cadangan besi dalam tubuh. Pemeriksaan kadar serum ferritin sudah rutin dikerjakan untuk menentukan diagnosis defisiensi besi, karena terbukti bahwa kadar serum ferritin sebagai indikator paling dini menurun pada keadaan bila cadangan besi menurun. Namun dalam keadaan infeksi kadarnya dipengaruhi, sehingga dapat mengganggu interpretasi keadaan sesungguhnya. ${ }^{9}$

\section{SIMPULAN}

Terdapat perbedaan rerata serum erithropoietin pada ibu hamil anemia dan ibu hamil normal,

Terdapat perbedaan rerata serum transferin pada ibu hamil anemia dan ibu hamil normal dan terdapat hubungan kadar serum erithropoietin dengan transferin pada ibu hamil anemia.

Tidak terdapat hubungan kadar serum erithropoietin dengan transferin pada ibu hamil normal.

\section{UCAPAN TERIMA KASIH}

Terima kasih kepada Ketua dan staff Laboratorium Biomedik Universitas Andalas Padang

\section{DAFTAR PUSTAKA}

1. Kementerian Kesehatan RI (Kemenkes RI). Riset kesehatan dasar (Riskesdas) Indonesia. Jakarta: Kemenkes RI; 2018.hlm.54.

2. Kementerian Kesehatan RI (Kemenkes RI). Riset kesehatan dasar (Riskesdas) Indonesia. Jakarta: Kementrian Kesehatan RI; 2013.hlm.49.

3. Kementerian Kesehatan RI (Kemenkes RI). Riset kesehatan dasar (Riskesdas) Indonesia. Jakarta: Kementrian Kesehatan RI; 2007.hlm.62.

4. Dinas Kesehatan Kota (DKK) Padang. Profil dinas kesehatan kota Padang 2018. Padang: Dinas Kesehatan Kota Padang; 2018.hlm.105.

5. Flesland $O$, Eskeland AK, Flesland AB, Falch D, Solheim BG, Seghatchian J. Transferrin receptor in serum. A new tool in the diagnosis and prevention of iron deficiency in blood donors. Transfus Apher Sci. 2004;31:11-6.

6. Khalid S, McGrowder D, Kemp M, Johnson P. The use of soluble transferrin receptor to assess iron deficiency in adults with cystic fibrosis. Clin Chim Acta. 2007;378:194- 200.

7. Ghezzi P, Brines M. Erythropoietin as an antiapoptotic, tissue-protective cytokine. Cell Death Differ. 2004;11(1): S37-S44.

8. Lin $X M$, Tian $W, M a ~ L$, Long Z, Zhang J, Shen $X Y$, Zhang XP. The responses of serum transferrin receptors to iron supplements in subjects with irondeficiency erythropoiesis and iron-deficiency anemia. Br J Nutr. 2008;99:416-20.

9. Sharma JB, Bumma SD, Saxena R, Kumar S, Roy KK, Singh N, Vanamail P. Cross sectional, comparative study of serum erythropoietin, transferrin receptor, ferritin levels and other hematological indices in normal pregnancies and iron deficiency anemia during pregnancy. Eur $\mathrm{J}$ Obstet Gynecol Reprod Biol. 2016;203:99-103.

10. Goldstein JD, Garry DJ, Maulik D. Obstetric conditions and erythropoietin levels. Am J Obstet Gynecol. 2000;182:1055-7.

11. Proverawati A. Anemia dan anemia kehamilan. Yogyakarta: NuhaMedik; 2007.

12. Flesland O, Eskeland AK, Flesland AB, Falch D, Solheim BG, Seghatchian J. Transferrin receptor in serum. A new tool in the diagnosis and 
prevention of iron deficiency in blood donors. Transfus Apher Sci. 2004;31:11-6.

13. Peng $H$, Jaroslav $T$, Lee $P$. Iron-deficiency anemia from matriptase-2 inactivation is dependent on the presence of functional Bmp6. Changes. 2012; 29(6): 997-1003.
14. Ervasti M, Kotisaari S, Heinonen S, Punnonen K. Elevated serum erythropoietin concentration is associated with coordinated changes in red blood cell and reticulocyte indices of pregnant women at term. The Scandinavian Journal of Clinical \&Laboratory Investigation. 2008;68(2):160-65. 